\title{
Altered Expression of DDR1 in Clear Cell Renal Cell Carcinoma Correlates With miR-199a/b-5p and Patients' Outcome
}

\author{
BARTLOMIEJ E. KRAZINSKI ${ }^{*}$, JOLANTA KIEWISZ ${ }^{1 *}$, AGNIESZKA SLIWINSKA-JEWSIEWICKA ${ }^{1}$, \\ ANNA E. KOWALCZYK ${ }^{1}$, JEDRZEJ GRZEGRZOLKA ${ }^{2}$, JANUSZ GODLEWSKI ${ }^{1}$, \\ PRZEMYSLAW KWIATKOWSKI ${ }^{1}$, PIOTR DZIEGIEL $^{2,3}$ and ZBIGNIEW KMIEC ${ }^{1,4}$ \\ ${ }^{I}$ Department of Human Histology and Embryology, University of Warmia and Mazury in Olsztyn, Olsztyn, Poland; \\ ${ }^{2}$ Department of Human Morphology and Embryology, \\ Division of Histology and Embryology, Wroclaw Medical University, Wroclaw, Poland; \\ ${ }^{3}$ Department of Physiotherapy, Wroclaw University School of Physical Education, Wroclaw, Poland; \\ ${ }^{4}$ Department of Histology, Medical University of Gdansk, Gdansk, Poland
}

\begin{abstract}
Background/Aim. Accumulating evidence suggests that discoidin domain receptor tyrosine kinase 1 (DDR1) has an oncogenic role. Therefore, the aim of this study was to evaluate the potential utility of DDRI and its posttranscriptional repressors, miR-199a-5p and miR-199b-5p, as prognostic factors in clear cell renal cell carcinoma (ccRCC). Patients and Methods. The expression of DDRI in tumor and normal renal tissues of 56 patients with ccRCC was assessed by reverse transcription quantitative polymerase chain reaction, western blotting and immunohistochemistry. Renal cancer cells were transfected with specific RNA sequences to validate DDRI as a putative miR-199a/b-5p target. Results. Decreased DDRI $m R N A$ and protein, as well as miR-199a/b-5p levels were found in ccRCC. Low DDRI protein was associated with higher nuclear grade and shorter overall survival. DDRI immunoreactivity was elevated in the nuclei and unchanged in the membrane/cytoplasmic compartment of tumor cells. DDRI levels correlated with those of miR-199a/b-5p. In addition, we validated DDRl as a target gene for miR-199a/b-5p in renal cancer cell lines. Conclusion. DDRI expression is altered in
\end{abstract}

This article is freely accessible online.

*These Authors contributed equally to this study.

Correspondence to: Bartlomiej E Krazinski, Ph.D., Department of Human Histology and Embryology, School of Medicine, Collegium Medicum, University of Warmia and Mazury in Olsztyn, 30 Warszawska Str., 10-082 Olsztyn, Poland. Tel: +48 895245310, Fax: +48 895245306, e-mail: bartlomiej.krazinski@uwm.edu.pl

Key Words: DDR1, miR-199a-5p, miR-199b-5p, clear cell renal cell carcinoma.
ccRCC, but our findings do not support its oncogenic role. Indepth investigation will be necessary to elucidate the exact role and potential utility of miR-199a/b-5p in $c c R C C$.

Renal cell carcinoma (RCC) is considered one of the most lethal urological malignancies representing the sixth and tenth most frequently diagnosed cancers in men and women, respectively (1). The most prevalent histological subtype of RCC, clear cell renal cell carcinoma (ccRCC) comprises 70$80 \%$ of renal tumors (2). It is believed that clear cell tumors originate in the proximal convoluted tubule (PCT) $(3,4)$. The majority of ccRCC sporadic cases are characteristically associated with the loss of function of von Hippel-Lindau (VHL) tumor-suppressor gene by somatic mutations, chromosomal loss or promoter hypermethylation (5). Loss or inactivation of VHL results in a sequence of events comprising accumulation of hypoxia inducible factors (HIFs), overexpression of HIF-driven genes such as vascular endothelial growth factor (VEGF), promotion of angiogenesis, cell proliferation and tumor growth (5). Surgical resection is the mainstay of treatment of localized renal tumors, although a significant number of these patients will eventually develop recurrent or metastatic disease (2). Better understanding of ccRCC molecular background allowed for introduction of new therapeutics that target VEGF and mammalian target of rapamycin (mTOR) pathways and can be applied in the adjuvant pharmacotherapy of advanced or metastatic tumors. However, the benefits of ccRCC adjuvant therapies are still far below expectations and complete and durable responses are rare (4). At present, RCC recurrence risk stratification models are primarily based on the American Joint Committee on Cancer (AJCC) pathological tumor-node-metastasis (TNM) classification and histopathological features $(2,4,6)$. To date, 
despite many efforts, there is no consensus on the routine use of molecular biomarkers to improve the surveillance protocols for follow-up of ccRCC patients after nephrectomy and predict of pharmacotherapy responsiveness $(2,4,6)$.

The discoidin domain receptor 1 (DDR1) is a unique collagen receptor that belongs to the tyrosine receptor family (7-9). DDR1 exists as homodimers at the plasma membrane which act as a collagen sensors that bind to native triple helix form of collagen types I to IV and VIII $(10,11)$. DDRI expression is predominant in epithelial cells and this receptor is a key molecule that maintains cell-to-extracellular matrix (ECM) crosstalk. DDR1 influences a number of physiological processes and also plays a significant role in a number of pathological processes including tissue fibrosis and neoplastic diseases (11). DDRl is often deregulated in many human neoplasms including the cancers of lung, breast, liver, pancreas and ovary as well as leukemias (12, 13). The involvement of DDR1 in the processes of tissue remodeling and its central role in the development of fibrotic lesions strongly suggest that abnormal expression of this receptor may affect, besides intracellular pathways, interactions of cancer cells with the ECM components (11). Therefore, in addition to the control of adhesion, proliferation and survival of cancer cells, DDR1 was proposed as a trigger of epithelial to mesenchymal transition (EMT) and its pro-invasive activity was proved in a variety of human cancer cell lines $(12,13)$. However, the precise mechanisms by which DDR1 may contribute to oncogenesis have not been fully elucidated. The experimental data are often conflicting and the exact impact of DDR1 on carcinogenesis remains disputable $(14,15)$.

So far, the prognostic significance of DDR1 in ccRCC was investigated in only one study performed on a Chinese population (16). It was reported that high levels of DDR1 immunoreactivity correlated with the progression of ccRCC and shorter overall survival (OS) of the patients (16). Interestingly, these findings (16) are discordant with the survival analysis available at the Human Protein Atlas website, demonstrating that high expression of $D D R l$ correlates with favorable prognosis in ccRCC (17). Therefore, the main purpose of the present study was to assess $D D R l$ expression in the paired, tumor and non-cancerous tissue samples of 56 patients with ccRCC by reverse transcription quantitative polymerase chain reaction (RT-qPCR), western blotting (WB) and immunohistochemistry (IHC), and evaluate the prognostic significance of $D D R 1$. In addition, the mechanisms that could underlay altered $D D R 1$ expression in ccRCC, comprising miR199a-5p and miR-199b-5p, were investigated in ccRCC tumor tissue samples and renal cancer cell lines.

\section{Patients and Methods}

Ethical approval. This study was approved by the Bioethics Committee for Scientific Research at the University of Warmia and Mazury in Olsztyn, Poland (agreements no. 4/2010 and 44/2011).
Written informed consent as specified in the Declaration of Helsinki (1964) was obtained from each patient.

Patients and the collection of samples. Specimens were obtained from postoperative material of 56 patients with histologically confirmed ccRCC (27 men and 29 women; mean age \pm SD, $63.9 \pm 11.0$; range $=27-83$ years) who were operated on at the Department of Oncological Surgery, Warmia and Mazury Oncological Center in Olsztyn, Poland, between March 2010 and July 2014. None of patients included in the study had a second neoplastic disease or had previously undergone chemo- or radiotherapy. Clinical and demographic data were obtained at the time of enrollment. Data on the OS were collected and the median follow-up time was 40.6 months. During this time 22/56 (39.3\%) patients died. Clinical staging was based on the AJCC criteria (18). The tumor and matched macroscopically unchanged renal tissue samples were obtained from surgically resected kidneys as previously described (19). Specimens for RT-qPCR or western blotting were immediately frozen in a liquid nitrogen and stored at $-80^{\circ} \mathrm{C}$. Tissue fragments for routine histological evaluation and immunohistochemistry were fixed in $4 \%$ buffered formaldehyde, dehydrated in a series of ethanol solutions in ascending concentrations, cleared in xylene and processed into paraffin blocks. The tumor nuclear grading was characterized by pathologist according to the Fuhrman system (20).

DDR1 mRNA quantification. Total RNA was extracted and reverse transcribed as previously described $(21,22)$. The levels of $D D R 1$ transcripts in homogenates of paired tumor and renal tissue specimens were determined by RT-qPCR and normalized to peptidylprolylisomerase A (PPIA) and TATA box binding protein (TBP) mRNAs content. The reactions were carried out using TaqMan Fast Advanced Master Mix, and the respective TaqMan Gene Expression Assay (DDR1, \#Hs01058430_m1; PPIA, \#Hs99999904_m1; TBP, \#Hs00427620_m1) in an ABI 7500/7500 Fast Real-Time PCR System (all: Applied Biosystems; Thermo Fisher Scientific, Inc., Waltham, MA, USA). The thermocycling conditions were as follows: polymerase activation for $20 \mathrm{sec}$ at $95^{\circ} \mathrm{C}$, followed by 40 cycles of denaturation for $3 \mathrm{sec}$ at $95^{\circ} \mathrm{C}$ and annealing/extension for $30 \mathrm{sec}$ at $60^{\circ} \mathrm{C}$. All samples were amplified in duplicates. The $\Delta \Delta \mathrm{Cq}$ method (23) was used to determine the fold differences in DDRl expression between the paired samples of ccRCC and unchanged renal tissue. Based on the median DDR1 transcript content in the tumor samples, patients were divided into two groups regarded as having 'low' or 'high' levels of DDR1 mRNA.

miR-199a-5p and miR-199b-5p quantitation. Total RNA was extracted and reverse transcribed as previously described (24). The levels of miR-199a-5p and miR-199b-5p in homogenates of paired tumor and normal renal tissue specimens were determined by RTqPCR and normalized to small nucleolar RNA RNU48 content. The reactions were performed using TaqMan Universal PCR Master Mix and the respective TaqMan MicroRNA Assay (miR-199a-5p, \#000498; miR-199b-5p, \#000500; RNU48, \#001006) in an ABI 7500/7500 Fast Real-Time PCR System (all: Applied Biosystems; Thermo Fisher Scientific, Inc.). The thermocycling conditions were as follows: polymerase activation for $10 \mathrm{~min}$ at $95^{\circ} \mathrm{C}$, followed by 40 cycles of denaturation for $15 \mathrm{sec}$ at $95^{\circ} \mathrm{C}$ and annealing/extension for $1 \mathrm{~min}$ at $60^{\circ} \mathrm{C}$. All samples were amplified in duplicates. The $\Delta \Delta \mathrm{Cq}$ method (23) was used to determine the fold differences in miRs expression between the paired samples of ccRCC and 
unchanged renal tissue. Based on the median miR-199a-5p or miR$199 \mathrm{~b}-5 \mathrm{p}$ content in the tumor samples, the patients were divided into two groups regarded as having 'low' or 'high' levels of miR-199a$5 \mathrm{p}$ or miR-199b-5p.

DDR1 protein quantification. Protein extraction, SDS-PAGE and WB were carried out according to the modified method described previously (21). The levels of protein in homogenates of paired tumor and normal renal tissue specimens were determined using rabbit anti-human antibodies against DDR1 (diluted 1:500; \#sc-532; Santa Cruz Biotechnology, Dallas, TX, USA) and actin beta (ACTB; diluted 1:100; \#A2066; Sigma-Aldrich) as internal loading control. DDR1/ACTB optical density (OD) ratios were used to determine fold differences in expression between the paired samples of ccRCC and unchanged renal tissue. Based on the median DDR1 protein content in tumor specimens, patients were divided into two groups regarded as having 'low' or 'high' levels of DDR1 protein.

IHC and evaluation of immunoreactivity. DDR1 immunostaining of the tumor and non-cancerous kidney sections was carried out using the Autostainer Link48 (Dako Cytomation, Glostrup, Denmark) according to the previously described method (25). Rabbit antibody directed against human DDR1 was applied (1:300; \#sc-532; Santa Cruz Biotechnology) whereas negative controls were obtained by omitting the primary antibody. The DDR1 immunostained sections were evaluated using Olympus BX53 light microscope (Olympus, Tokyo, Japan) by two independent pathologists in a blinded manner regarding the clinical data of the patients. In doubtful cases, reevaluation was performed until a consensus was achieved. Immunoexpression of DDR1 was assessed in the cytoplasm of cancer cells and non-transformed, normal epithelial cells of the proximal convoluted tubules (PCTs). The membrane/cytoplasmic immunoreactivity of DDR1 was evaluated according to the immunoreactive score (IRS) of Remmele and Stegner (26). The IRS scale is based on the percentage of cells exhibiting positive reaction ( 0 points, absence of cells with positive reaction; 1 point, $1-10 \% ; 2$ points, $11-50 \%$; 3 points, $51-80 \%$; 4 points, $>80 \%$ cells with positive reaction) and reaction intensity $(0$, no reaction; 1 , low intensity reaction; 2 , moderate intensity reaction; 3 , intense reaction). The final score is the result of multiplication of both parameters and ranges from 0 to 12 points). The nuclear DDR1 immunoreactivity was evaluated semi-quantitatively based on the percentage of cells presenting positive expression of DDR 1 and encoded as follows: 0 - absence of staining, 1 point when $1-10 \%$ cells stained, 2 points when $11-50 \%, 3$ when $51-80 \%$, and 4 points when $81-100 \%$. Based on their DDR1 immunostaining in membrane/cytoplasm of ccRCC cells the patients were divided into two groups regarded as 'negative' (IRS=0) or 'positive' (IRS $\geq 1$ ). Similarly, depending on the absence or presence of DDR1 immunoexpression on the nuclei of ccRCC cells, patients were divided into two groups regarded as 'negative' ( score $=0$ ) or 'positive' (score $\geq 1$ ), respectively.

Cell lines and cell culture. Human RCC cell lines Caki-1 (HTB-46), Caki-2 (HTB-47), ACHN (CRL-1611) and a control line, HK-2 (CRL-2190; immortalized cells established from normal epithelium of proximal tubule) were obtained from the American Type Culture Collection (ATCC; Manassas, VA, USA). Caki-1 and Caki-2 cells were maintained in McCoy's 5A medium (Sigma-Aldrich; Merck, KGaA, Darmstadt, Germany), ACHN cells in Eagle's Minimum Essential Medium (ATCC) and HK-2 cells in Dulbecco's Modified
Eagle's Medium/Nutrient Mixture F-12 Ham (Sigma-Aldrich; Merck, $\mathrm{KGaA}$ ). All culture media were supplemented with $10 \%$ fetal bovine serum (Sigma-Aldrich; Merck, KGaA). Cell lines were incubated at $37^{\circ} \mathrm{C}$ in $5 \% \mathrm{CO}_{2}$.

DDR1 silencing by miR-199a-5p and miR-199b-5p. The transfections were carried out according to the manufacturer's instructions using reverse transfection protocol adjusted for a 6 -well plate culture. $2 \times 10^{5}$ cells were seeded into a well containing preactivated mixture of 50 pmol mimic (miR-199a-5p, \#MC10893; miR-199b-5p, \#MC10553; Ambion; Thermo Fisher Scientific, Inc., Waltham, MA, USA) or inhibitory (miR-199a-5p, \#MH10893; miR199b-5p, \#MH10553; Ambion; Thermo Fisher Scientific, Inc) RNA diluted in Opti-MEM Reduced Serum Medium (Gibco, Thermo Fisher Scientific, Inc., Waltham, MA, USA) and $7 \mu \mathrm{l}$ of Lipofectamine RNAiMAX and incubated for $16 \mathrm{~h}$ prior to replacement with fresh medium. Nonsense mimic or inhibitor RNA sequences were used as negative controls (mirVana miRNa mimic Negative Control \#1; mirVana miRNa inhibitor Negative Control \#1; Ambion, Thermo Fisher Scientific, Inc.). Three independent transfections were carried out for every cell line. All transfections within a single experiment were performed in duplicates. The cells were harvested $72 \mathrm{~h}$ post-transfection and assayed for DDRl expression levels using $\mathrm{qPCR}$ and $\mathrm{WB}$ as described above.

\section{Statistical analyses.}

The statistical analyses were carried out with Prism 6.04 (Graphpad, LA Jolla, CA, USA) and Statistica 13.1 (Statsoft, Tulsa, OK, USA). The DDR1 and miRs expression levels are expressed as mean \pm SEM. The differences in DDRl or miR expression levels between the paired tumor and unchanged renal tissue specimens were examined by the Wilcoxon matched-pairs test. Fisher's exact, Mann-Whitney $U$-test and Spearman's rank correlation were used to assess correlations between the patients' data and DDRl or $m i R$ expression levels. Spearman's correlation coefficient was used to determine the relationship between the DDR1 and miR-199a-5p or miR-199b-5p expression levels. Survival curves were plotted according to the Kaplan-Meier method while the significance of differences in OS between groups of patients was evaluated by the $\log$-rank test. The uni- and multivariate survival associations were analyzed using the Cox proportional hazards regression model. The differences in $D D R 1$ expression levels between the cells transfected with mimics or inhibitor RNA sequences and respective control incubations were examined by Analysis of Variance followed by the Least Significant Difference post hoc test. In all performed analyses results were considered statistically significant for $p<0.05$.

\section{Results}

DDRl expression is down-regulated in ccRCC homogenates. $D D R 1$ transcripts were found in tumor and renal tissue samples of all patients included in the study. The tumor samples showed over 2-fold decrease in the expression levels of DDRl mRNA as compared to the corresponding unchanged renal tissues $(p<0.0001$; Figure 1A). Western blotting analysis revealed that DDR 1 protein was present in $84 \%(47 / 56)$ of ccRCC tumors and $95 \%$ (53/56) of normal kidney tissues samples. Consequently, the average DDR1 content in ccRCC specimens was reduced by nearly 1.4-fold 

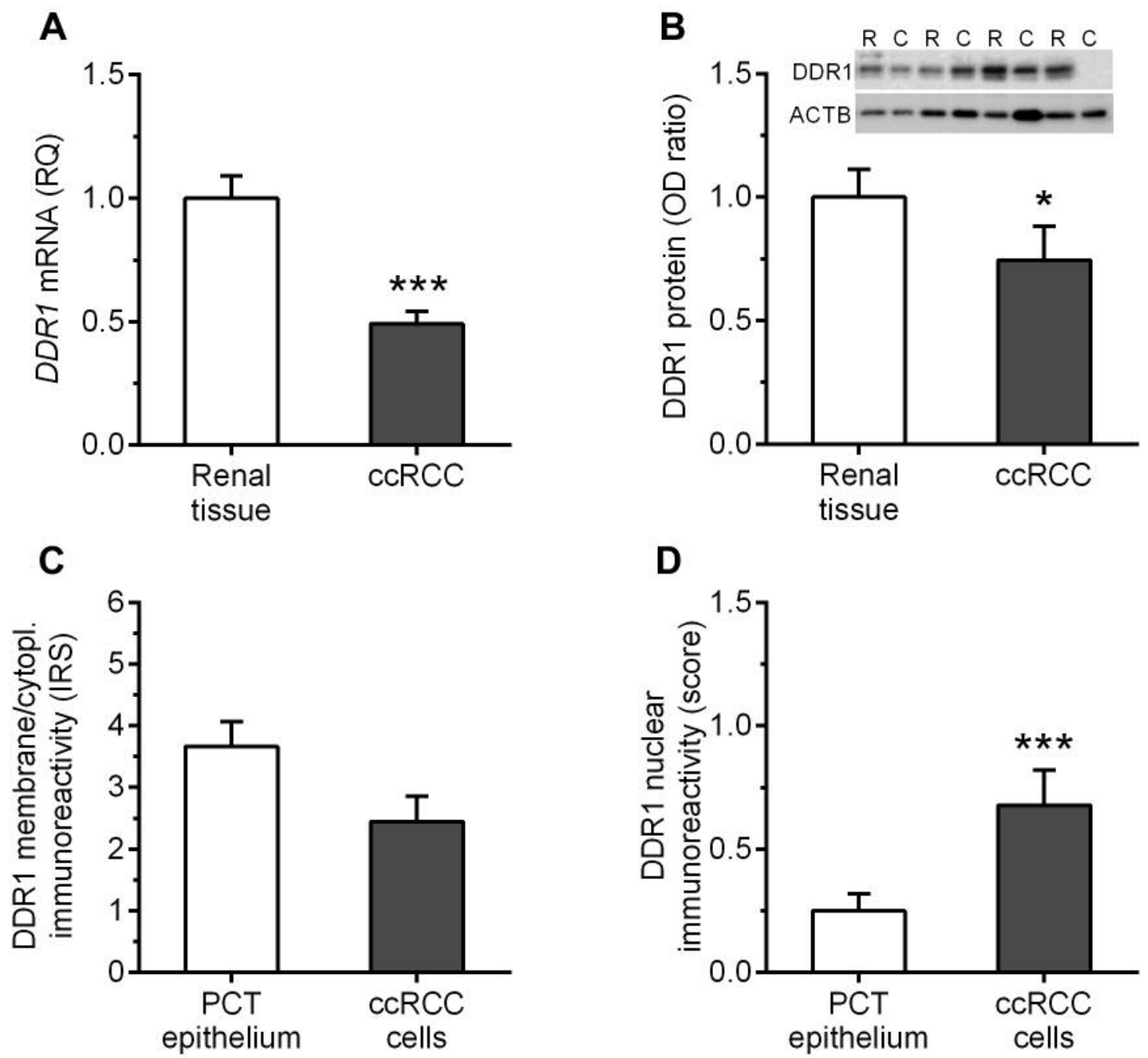

Figure 1. Average levels of discoidin domain receptor tyrosine kinase 1 (DDR1) in the clear cell renal cell carcinoma (ccRCC) specimens and corresponding renal tissue samples were determined by $(A)$ reverse transcription quantitative polymerase chain reaction, $(B)$ western blot and $(C$, D) immunohistochemistry. ${ }^{*} p<0.05 ; * * p<0.001 ; R Q$ : Relative quantification; OD: optical density; ACTB: actin beta; IRS: immunoreactivity score; PCT: proximal convolute tubule.

as compared to the corresponding renal tissues $(p=0.0113$; Figure 1B).

Decreased DDR1 protein levels in ccRCC are associated with higher nuclear grade. Low content of DDR1 protein in homogenates of ccRCC specimens correlated with higher Fuhrman nuclear grade $(p=0.0142$; Table I). Furthermore, the average DDR1 protein levels were over 2-fold lower in samples derived from G3/G4 tumors compared to G2 $(p=0.0095)$.

Altered membrane/cytoplasmic and nuclear DDRI immunohistochemical reactions in ccRCC. DDR1 immunoreactivity was observed in membrane/cytoplasmic and nuclear compartments of PCT epithelial cells (Figure 2A) and in the cancer cells of the analyzed specimens (Figure 2B). In addition to the PCT epithelial cells, IHC revealed the presence of DDR1 protein in cells of distal convoluted tubule and glomeruli in the sections of unchanged renal tissue. Among 56 tumor sections tested, the cancer cells of $29(52 \%)$ cases exhibited membrane/cytoplasmic DDR1 immunoreactivity. The average levels of DDR1 immunoexpression in the membrane/ cytoplasm of cancer cells and PCT epithelial cells of corresponding renal tissues were similar and did not differ significantly $(p=0.0712$; Figure 1C). DDR1 immunoexpression in the nuclei of cancer cells was noted in 20/56 (36\%) of ccRCC specimens. IHC revealed over 2.7 -fold increase in nuclear immunoreactivity of DDR1 in cancer cells as compared 
Table I. Associations between demographic and clinical-pathological features of clear cell renal cell carcinoma (ccRCC) patients and expression of discoidin domain receptor tyrosine kinase 1 (DDRI) gene at the mRNA and protein levels, as determined by quantitative polymerase chain reaction and western blotting, respectively, in homogenates of ccRCC.

\begin{tabular}{|c|c|c|c|c|c|c|c|}
\hline \multirow[t]{2}{*}{ Parameter } & \multirow{2}{*}{$\begin{array}{c}\text { Number } \\
\text { of cases } \\
\mathrm{n}(\%)\end{array}$} & \multicolumn{3}{|c|}{ DDR1 mRNA level in ccRCC } & \multicolumn{3}{|c|}{ DDR1 protein OD level in ccRCC } \\
\hline & & $\begin{array}{l}\text { Low } \\
\text { n (\%) }\end{array}$ & $\begin{array}{l}\text { High } \\
\text { n (\%) }\end{array}$ & $p$-Value & $\begin{array}{l}\text { Low } \\
\text { n (\%) }\end{array}$ & $\begin{array}{l}\text { High } \\
\mathrm{n}(\%)\end{array}$ & $p$-Value \\
\hline Total & 56 & $28(50)$ & $28(50)$ & & $28(50)$ & $28(50)$ & \\
\hline Men & $27(48)$ & $16(59)$ & $11(41)$ & 0.2847 & $15(56)$ & $12(44)$ & 0.5932 \\
\hline Women & $29(52)$ & $12(41)$ & $17(59)$ & & $13(45)$ & $16(55)$ & \\
\hline \multicolumn{8}{|l|}{ Age } \\
\hline$<62$ years old & $26(46)$ & $11(42)$ & $15(58)$ & 0.4218 & $13(50)$ & $13(50)$ & 1.0000 \\
\hline$\geq 62$ years old & $30(54)$ & $17(57)$ & $13(43)$ & & $15(50)$ & $15(50)$ & \\
\hline \multicolumn{8}{|l|}{ Tumor size } \\
\hline$<6 \mathrm{~cm}$ & $27(48)$ & $16(59)$ & $11(41)$ & 0.2847 & $10(37)$ & $17(63)$ & 0.1078 \\
\hline$\geq 6 \mathrm{~cm}$ & $29(52)$ & $12(41)$ & $17(59)$ & & $18(62)$ & $11(38)$ & \\
\hline \multicolumn{8}{|l|}{$\mathrm{T}$ status } \\
\hline $\mathrm{T} 1+\mathrm{T} 2$ & $30(54)$ & $15(50)$ & $15(50)$ & 1.0000 & $11(37)$ & $19(63)$ & 0.0598 \\
\hline $\mathrm{T} 3$ & $26(46)$ & $13(50)$ & $13(50)$ & & $17(65)$ & $9(35)$ & \\
\hline \multicolumn{8}{|l|}{ Fuhrman grade } \\
\hline $\mathrm{G} 2$ & $41(73)$ & $20(49)$ & $21(51)$ & 1.0000 & $16(39)$ & $25(61)$ & 0.0142 \\
\hline $\mathrm{G} 3+\mathrm{G} 4$ & $15(27)$ & $8(53)$ & $7(47)$ & & $12(80)$ & $3(20)$ & \\
\hline \multicolumn{8}{|c|}{ Distant metastases } \\
\hline Absent & $41(73)$ & $21(51)$ & $20(49)$ & 1.0000 & $44(18)$ & $23(56)$ & 0.2270 \\
\hline Present & $15(27)$ & $7(47)$ & $8(53)$ & & $67(10)$ & $5(33)$ & \\
\hline
\end{tabular}

Significant $p$-values $(<0.05)$ are shown in bold.

to PCT epithelium of non-cancerous kidney sections ( $p=0.0044$; Figure 1D). No correlations between DDR1 immunoreactivity and demographic or clinicopathological parameters of the patients were identified (Table II).

miR-199a-5p and miR-199b-5p are down-regulated in ccRCC homogenates. Both analyzed miRs were found in tumor and renal tissue samples of all patients included in the study. The average expression levels of miR-199a-5p and miR-199b-5p were nearly 2-fold reduced in ccRCC homogenates compared to corresponding renal tissues ( $p=0.0002$ and $p=0.0134$; Figure $3 \mathrm{~A}$ and B, respectively).

Expression levels of miR-199a-5p are associated with tumor growth. Higher content of miR-199a-5p correlated with bigger tumor size $(p=0.0315$; Table III). In addition, the average expression levels of miR-199a-5p were over 2 -fold higher in tumors equal or bigger than $6 \mathrm{~cm}$ compared to those characterized by a smaller diameter $(p=0.0249)$.

Low levels of DDRI protein are associated with an unfavorable prognosis. Kaplan-Meier plots presenting the OS of patients with ccRCC classified in respect to the DDR1 expression levels are presented in Figure 4. Low levels of DDR 1 protein expression were associated with shorter OS of the patients with ccRCC (median survival 37.7 months for low level of DDR1 protein group $v s . \geq 82.6$ months for high levels of DDR1 protein group; Figure 4B). The expression of $D D R 1$ transcript and DDR 1 immunoreactivity did not correlate with OS of the patients (Figure 4A, C and D, respectively). No statistically significant relationships were disclosed between the expression of miR-199a-5p and miR199b-5p and patients' outcome (Figure 4E and F, respectively). Univariate Cox proportional hazards regression revealed that low levels of DDR1 protein, bigger tumor size, higher T-status of the primary tumor, higher Fuhrman nuclear grade and presence of distant metastases are significantly associated with OS of the patients (Table IV, left panel). However, the subsequent multivariate analysis revealed that none of the parameters achieved a status of an independent prognostic factor in the analyzed group of patients with ccRCC (Table IV, right panel).

miR-199a-5p and miR-199b-5p correlate with expression of DDRl at the protein level. Significant negative correlation was found between the levels of miR-199b-5p and DDR1 protein in ccRCC specimens ( $\mathrm{Rho}=-0.3438, p=0.0095$; Table V). The content of miR-199a-5p showed a tendency to be negatively associated with DDR protein levels (Rho $=-0.2474, p=0.0660$; Table V). In addition, the specimens with higher content of DDR1 protein (>median) were characterized by over 2 and 9-fold decrease in miR-199a-5p and miR-199b-5p expression 

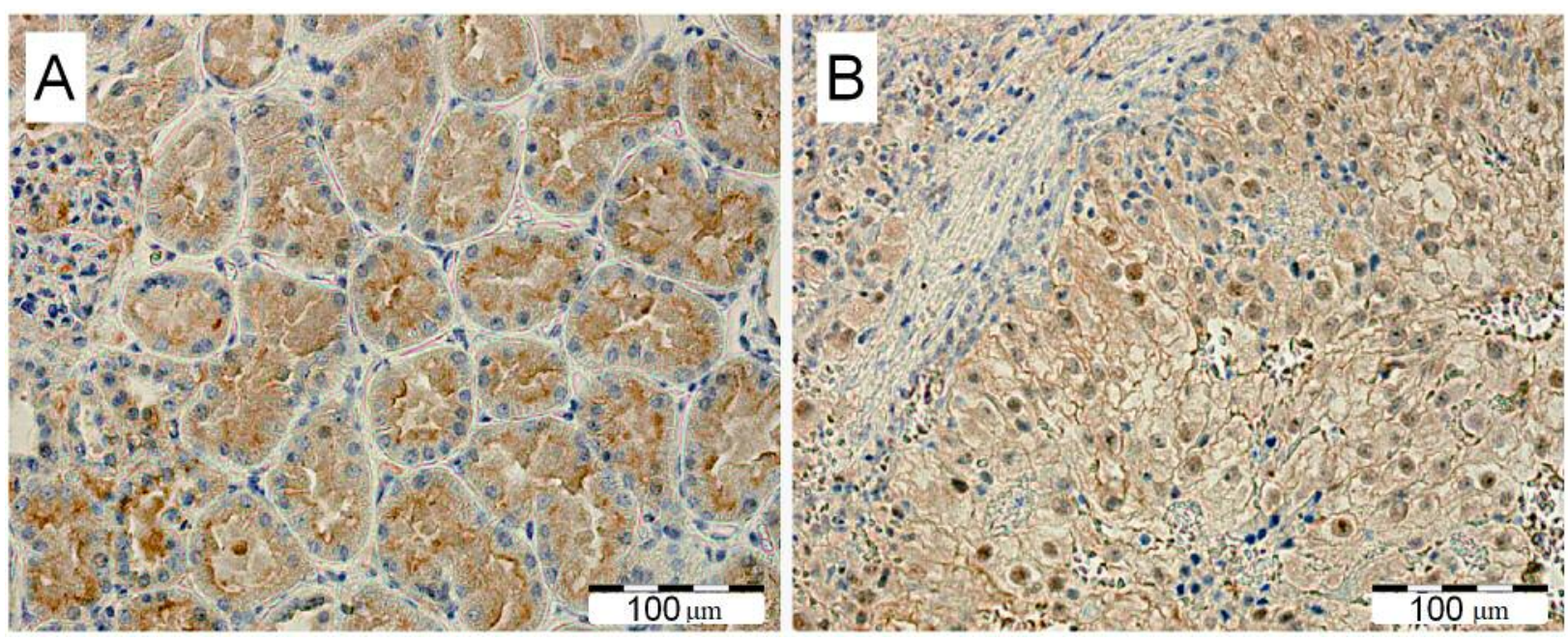

Figure 2. Evaluation of discoidin domain receptor tyrosine kinase 1 (DDR1) immunoexpression in the sections of (A) unchanged renal tissue and (B) tumor of representative patient with clear cell renal cell carcinoma was determined by immunohistochemistry. DDR1 protein was present in the membrane/cytoplasm of proximal convolute tubule epithelium and cancer cells. Most renal tissue specimens did not reveal nuclear immunoreactivity of DDR1 while approximately one third of tumor sections exhibited weak to moderate DDR1 immunoreactivity in the nuclei of cancer cells.

Table II. Associations between demographic and clinical-pathological features of clear cell renal cell carcinoma (ccRCC) patients and immunoreactivity (IR) of discoidin domain receptor tyrosine kinase 1 (DDR1) in the membrane/cytoplasm and nuclear compartments of ccRCC cells, as determined by immunohistochemistry.

\begin{tabular}{|c|c|c|c|c|c|c|c|}
\hline \multirow[t]{2}{*}{ Parameter } & \multirow{2}{*}{$\begin{array}{c}\text { Number } \\
\text { of cases } \\
\mathrm{n}(\%)\end{array}$} & \multicolumn{3}{|c|}{ DDR1 membrane/cytoplasmic in ccRCC cells } & \multicolumn{3}{|c|}{ IR DDR1 nuclear IR in ccRCC cells } \\
\hline & & $\begin{array}{c}\text { Negative } \\
\mathrm{n}(\%)\end{array}$ & $\begin{array}{c}\text { Positive } \\
\text { n (\%) }\end{array}$ & $p$-Value & $\begin{array}{c}\text { Negative } \\
\mathrm{n}(\%)\end{array}$ & $\begin{array}{c}\text { Positive } \\
\text { n (\%) }\end{array}$ & $p$-Value \\
\hline Total & 56 & $27(48)$ & $29(52)$ & & $36(64)$ & $20(36)$ & \\
\hline Men & $27(48)$ & $14(52)$ & $13(48)$ & 0.7893 & $16(59)$ & $11(41)$ & 0.5785 \\
\hline Women & $29(52)$ & $13(45)$ & $16(55)$ & & $20(69)$ & $9(31)$ & \\
\hline \multicolumn{8}{|l|}{ Age } \\
\hline$<62$ years & $26(46)$ & $11(42)$ & $15(58)$ & 0.4357 & $18(69)$ & $8(31)$ & 0.5796 \\
\hline$\geq 62$ years & $30(54)$ & $16(53)$ & $14(47)$ & & $18(60)$ & $12(40)$ & \\
\hline \multicolumn{8}{|l|}{ Tumor size } \\
\hline$<6 \mathrm{~cm}$ & $27(48)$ & $13(48)$ & $13(52)$ & 1.0000 & $16(59)$ & $11(41)$ & 0.5785 \\
\hline$\geq 6 \mathrm{~cm}$ & $29(52)$ & $14(48)$ & $15(52)$ & & $20(69)$ & $9(31)$ & \\
\hline \multicolumn{8}{|l|}{$\mathrm{T}$ status } \\
\hline $\mathrm{T} 1+\mathrm{T} 2$ & $30(54)$ & $14(47)$ & $16(53)$ & 1.0000 & $19(63)$ & $11(37)$ & 1.0000 \\
\hline $\mathrm{T} 3$ & $26(46)$ & $13(50)$ & $13(50)$ & & $17(65)$ & $9(35)$ & \\
\hline \multicolumn{8}{|c|}{ Fuhrman grade } \\
\hline $\mathrm{G} 2$ & $41(73)$ & $21(51)$ & $20(49)$ & 0.5523 & $28(68)$ & $13(32)$ & 0.3539 \\
\hline G3+G4 & $15(27)$ & $6(40)$ & $9(60)$ & & $8(53)$ & $7(47)$ & \\
\hline \multicolumn{8}{|c|}{ Distant metastases } \\
\hline Absent & $41(73)$ & $21(51)$ & $20(49)$ & 0.5523 & $26(63)$ & $15(37)$ & 1.0000 \\
\hline Present & $15(27)$ & $6(40)$ & $9(60)$ & & $10(67)$ & $5(33)$ & \\
\hline
\end{tabular}

levels, respectively, compared to tumors with lower DDR1 protein levels $(p=0.0304$ and $p=0.0163$; Figure $5 \mathrm{~A}$ and $\mathrm{B}$, respectively). In contrast, significant positive correlations were disclosed between the levels of miR-199a-5p and miR-199b$5 \mathrm{p}$ and DDR1 nuclear immunoreactivity score $(\mathrm{Rho}=0.3136$, $p=0.0186$ and Rho $=0.3179, p=0.0170$, respectively; Table V). Furthermore, the average levels of miR-199b-5p in the specimens positive for nuclear DDR1 immunoexpression were approximately 7 -fold increased compared to the tumors that did not reveal nuclear DDR1 immunoreactivity ( $p=0.0457$; Figure 
A

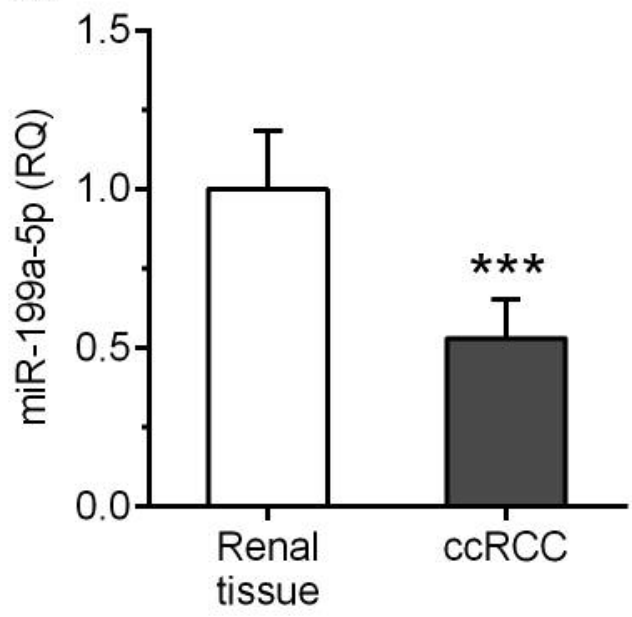

B

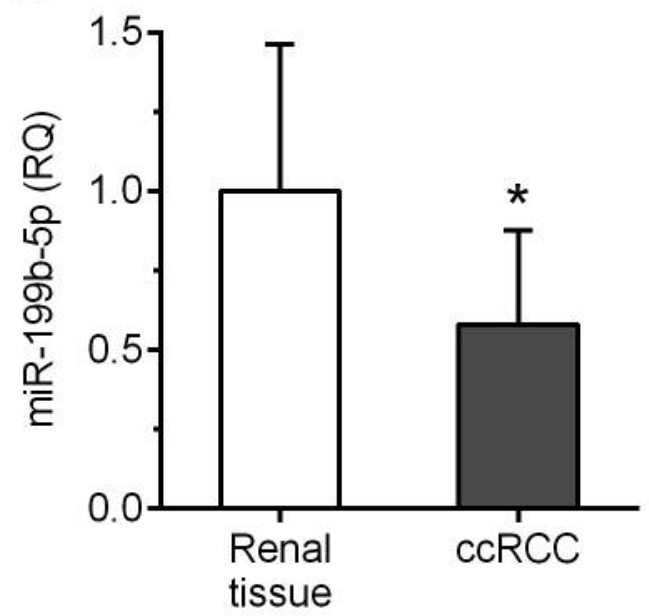

Figure 3. Average expression levels of miR-199a-5p and miR-199b-5p in the clear cell renal cell carcinoma (ccRCC) specimens and the corresponding renal tissue samples as determined by reverse transcription quantitative polymerase chain reaction. $* * * p<0.001 ; * p<0.05 ; R Q$ : Relative quantification.

Table III. Associations between demographic and clinical-pathological features of clear cell renal cell carcinoma (ccRCC) patients and expression levels of miR-199a-5p and miR-199b-5p in ccRCC, as determined by quantitative polymerase chain reaction in ccRCC homogenates.

\begin{tabular}{|c|c|c|c|c|c|c|c|}
\hline \multirow[t]{2}{*}{ Parameter } & \multirow{2}{*}{$\begin{array}{c}\text { Number } \\
\text { of cases } \\
\mathrm{n}(\%)\end{array}$} & \multicolumn{3}{|c|}{ miR-199a-5p level in ccRCC } & \multicolumn{3}{|c|}{ miR-199b-5p level in ccRCC } \\
\hline & & $\begin{array}{c}\text { Low } \\
\text { n }(\%)\end{array}$ & $\begin{array}{l}\text { High } \\
\text { n }(\%)\end{array}$ & $p$-Value & $\begin{array}{c}\text { Low } \\
\mathrm{n}(\%)\end{array}$ & $\begin{array}{l}\text { High } \\
\text { n }(\%)\end{array}$ & $p$-Value \\
\hline Total & 56 & $28(50)$ & $28(50)$ & & $28(50)$ & $28(50)$ & \\
\hline Men & $27(48)$ & $15(56)$ & $12(44)$ & 0.5932 & $15(56)$ & $12(44)$ & 0.5932 \\
\hline Women & $29(52)$ & $13(45)$ & $16(55)$ & & $13(45)$ & $16(55)$ & \\
\hline \multicolumn{8}{|l|}{ Age } \\
\hline$<62$ years old & $26(46)$ & $14(54)$ & $12(46)$ & 0.7891 & $13(50)$ & $13(50)$ & 1.0000 \\
\hline$\geq 62$ years old & $30(54)$ & $14(47)$ & $16(53)$ & & $15(50)$ & $15(50)$ & \\
\hline \multicolumn{8}{|l|}{ Tumor size } \\
\hline$<6 \mathrm{~cm}$ & $27(48)$ & $18(67)$ & $9(33)$ & 0.0315 & $17(63)$ & $10(37)$ & 0.1078 \\
\hline$\geq 6 \mathrm{~cm}$ & $29(52)$ & $10(34)$ & $19(66)$ & & $11(38)$ & $18(62)$ & \\
\hline \multicolumn{8}{|l|}{$\mathrm{T}$ status } \\
\hline $\mathrm{T} 1+\mathrm{T} 2$ & $30(54)$ & $17(57)$ & $13(43)$ & 0.4218 & $17(57)$ & $13(43)$ & 0.4218 \\
\hline T3 & $26(46)$ & $11(42)$ & $15(58)$ & & $11(42)$ & $15(58)$ & \\
\hline \multicolumn{8}{|l|}{ Fuhrman grade } \\
\hline $\mathrm{G} 2$ & $41(73)$ & $24(59)$ & $17(41)$ & 0.0683 & $23(56)$ & $18(44)$ & 0.0683 \\
\hline $\mathrm{G} 3+\mathrm{G} 4$ & $15(27)$ & $4(27)$ & $11(73)$ & & $5(33)$ & $10(67)$ & \\
\hline \multicolumn{8}{|c|}{ Distant metastases } \\
\hline Absent & $41(73)$ & $23(56)$ & $18(44)$ & 0.2270 & $23(56)$ & $18(44)$ & 0.2270 \\
\hline Present & $15(27)$ & $5(33)$ & $10(67)$ & & $5(33)$ & $10(67)$ & \\
\hline
\end{tabular}

Significant $p$-values $(<0.05)$ are shown in bold.

5D). Similarly, homogenates derived from nuclear-DDR1 positive tumors exhibited over 2-fold elevation in miR-199a$5 \mathrm{p}$ expression levels compared to tumors which lacked nuclear DDR1 immunoreactivity, however, this difference did not achieve statistical significance ( $p=0.0517$; Figure 5C).
miR-199a-5p and miR-199b-5p regulate the expression of DDRl in RCC cells. The expression of DDRl transcript and protein was present in all analyzed cell cultures under control conditions, i.e. untreated or transfected by a nonsense RNA sequences (Figure 6E). Transfection with miR-199a-5p or 

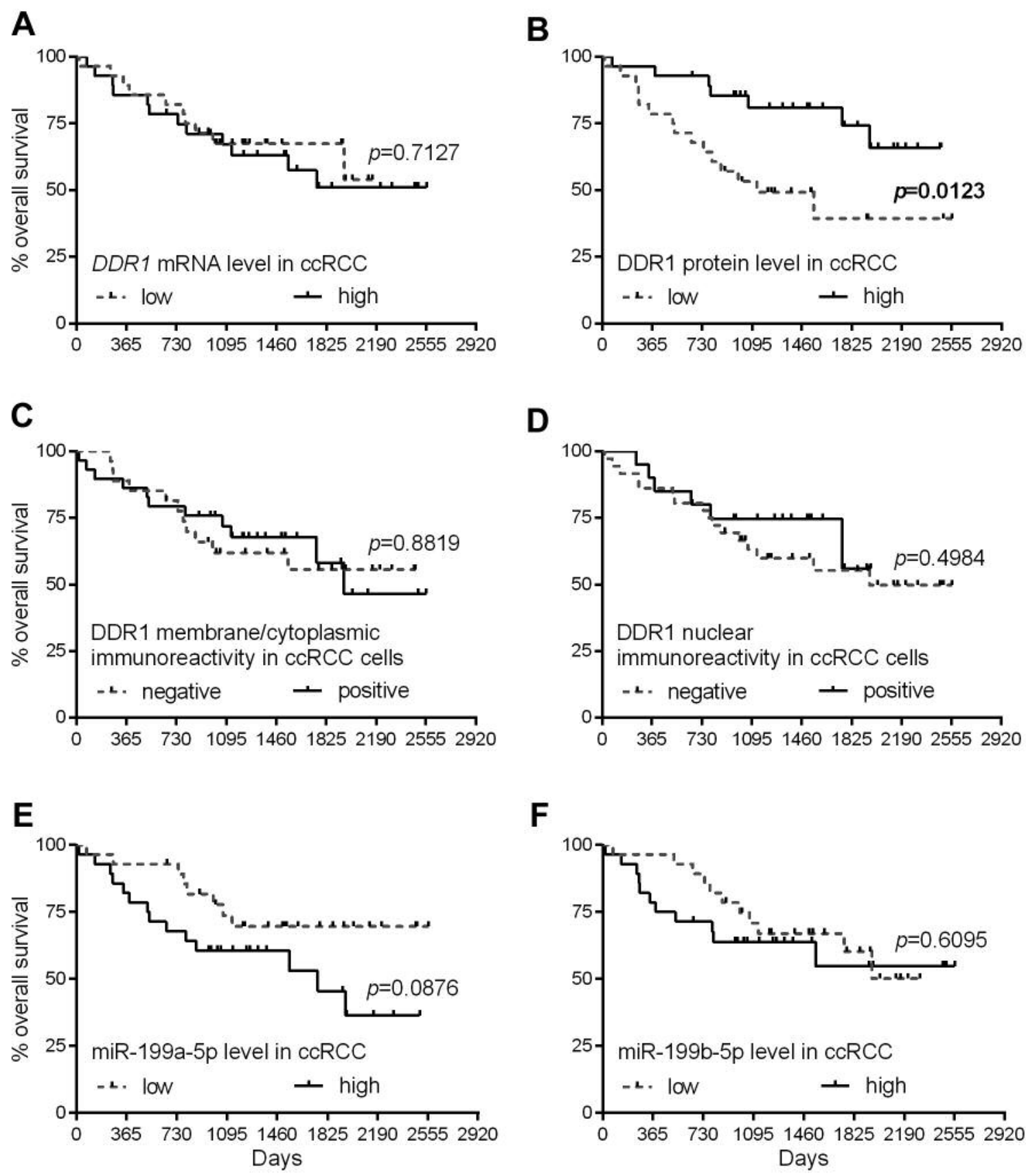

Figure 4. Kaplan-Meier diagrams of overall survival of patients with clear cell renal cell carcinoma (ccRCC) regarding discoidin domain receptor tyrosine kinase 1 (DDR1) expression at the (A) mRNA and (B) protein OD levels, DDR1 immunoreactivity in $(C)$ membrane/cytoplasm and $(D)$ nuclear compartments, as well as $(E)$ miR-199a-5p and $(F)$ miR-199b-5p content in ccRCC tissue homogenates. p-Values for the corresponding log-rank test are shown.

miR-199b-5p mimics significantly reduced $D D R 1 \mathrm{mRNA}$ in Caki-1 $(p=0.0009$ and $p<0.0001$, respectively), Caki-2 $(p<0.0001)$, ACHN ( $p=0.0004$ and $p=0.0065$, respectively) and HK-2 $(p<0.0001)$ cell lines, ranging from 3.9 to 8.6 -fold decrease compared to the cells transfected with nonsense mimic RNA sequences (Figure 6A). Furthermore, all the cell lines transfected with miR-199a-5p or miR-199b-5p exhibited reduced levels of DDR1 protein expression that ranged from 1.8 to 11.9 -fold decrease as compared to negative controls, but this repression achieved a statistical significance in Caki-2 ( $p=0.0023$ and $p=0.0087$, respectively) and ACHN ( $p=0.0022$ and $p=0.0039$ ) cells only (Figure 6B and E). In contrast, 
A

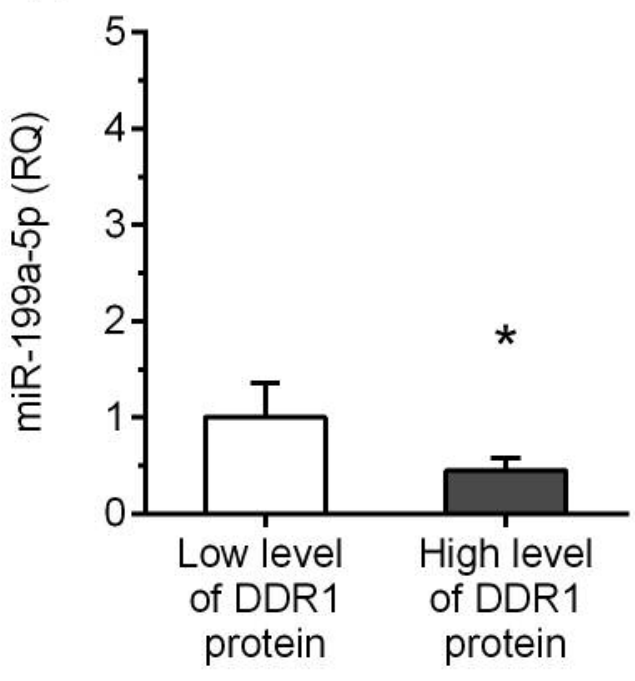

C

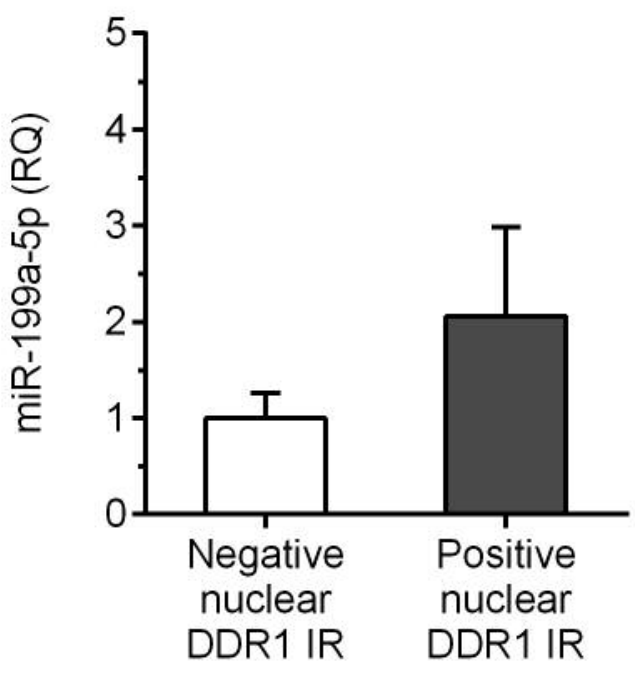

B

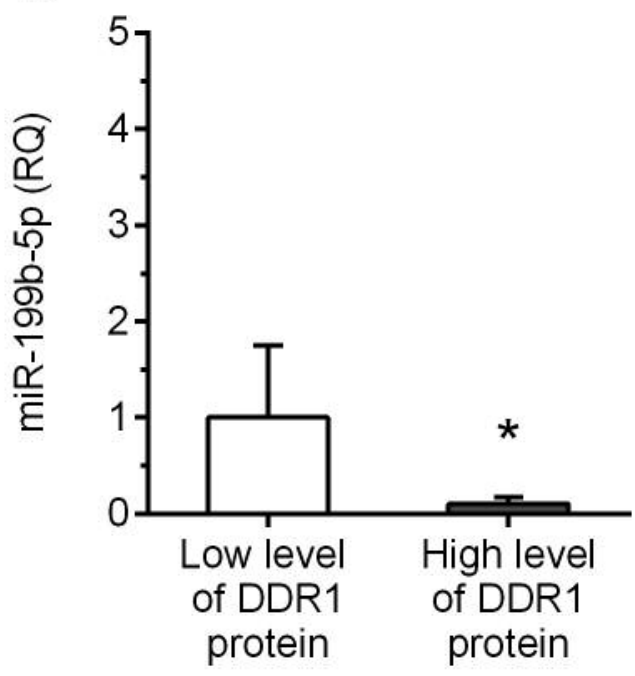

D

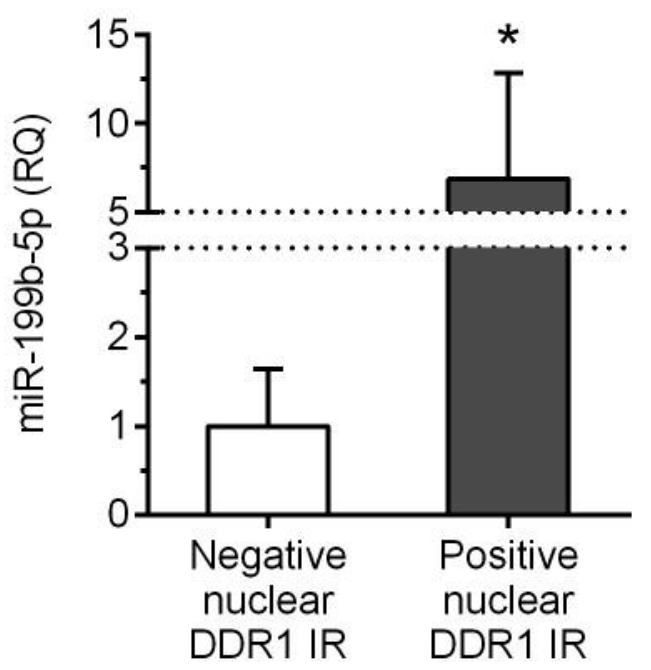

Figure 5. Correlations between the expression levels of discoidin domain receptor tyrosine kinase 1 (DDR1) protein and miR-199a-5p/miR-199b$5 p$ in the clear cell renal cell carcinoma (ccRCC) specimens. Average expression levels of miR-199a-5p and miR-199b-5p in the tumors of patients with ccRCC in respect to $(A$ and $B) D D R 1$ protein $O D$ and $(C$ and $D)$ nuclear DDR1 immunoreactivity. ${ }^{*} p<0.05$; RQ: Relative quantification; IR: immunoreactivity.

transfection of the cell lines with miR-199a-5p or miR-199b$5 \mathrm{p}$ inhibitors had no significant influence on $D D R I$ expression levels (Figure 6C, D and E).

\section{Discussion}

This study provides a novel insight into the significance of $D D R I$ as a putative prognostic factor in ccRCC. Reduced levels of $D D R I$ expression in the tumor tissues correlated with higher nuclear grade and shorter OS of the patients. Tumor cells exhibited altered DDR1 immunoreactivity reflected by the up-regulated nuclear expression of this protein. In addition, the putative post-transcriptional repressors of $D D R 1$ expression, miR-199a-5p and miR-199b-5p, were down-regulated in the tumor specimens. To the best of our knowledge the present study is the first to demonstrate that miR-199a-5p and miR199b-5p expression levels correlate with the content of DDR1 protein in tumor tissue samples collected from patients with 
A

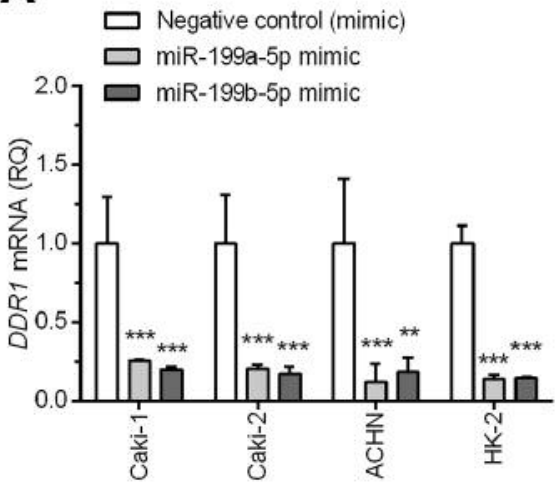

C

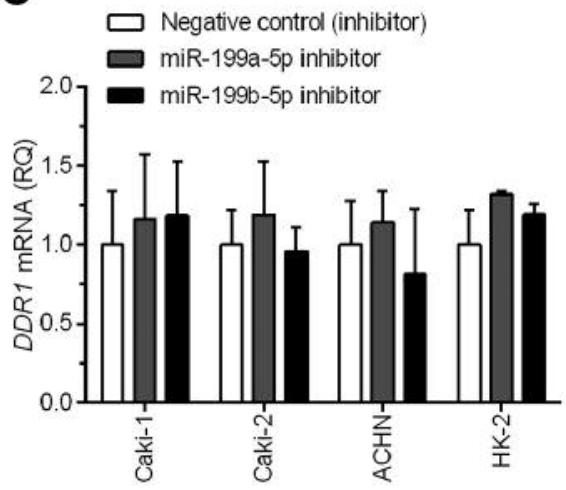

B

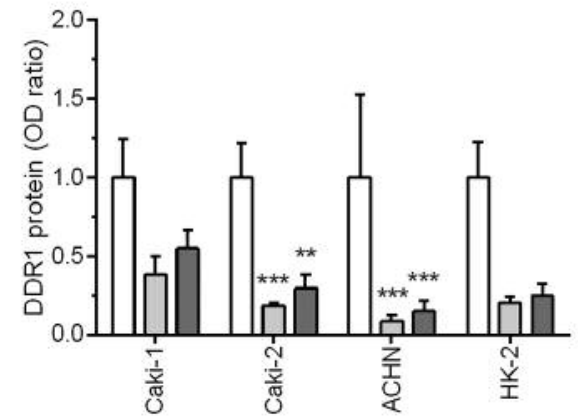

D

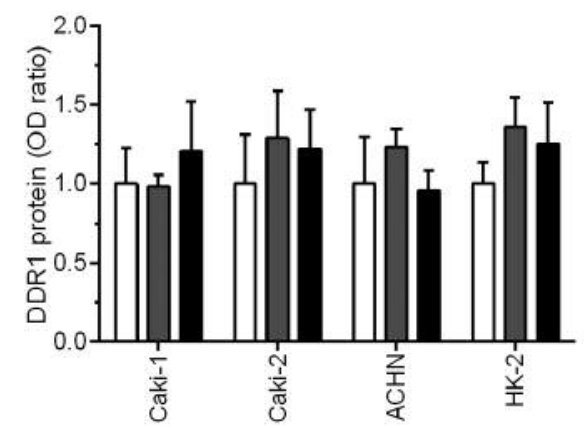

$\mathbf{E}$

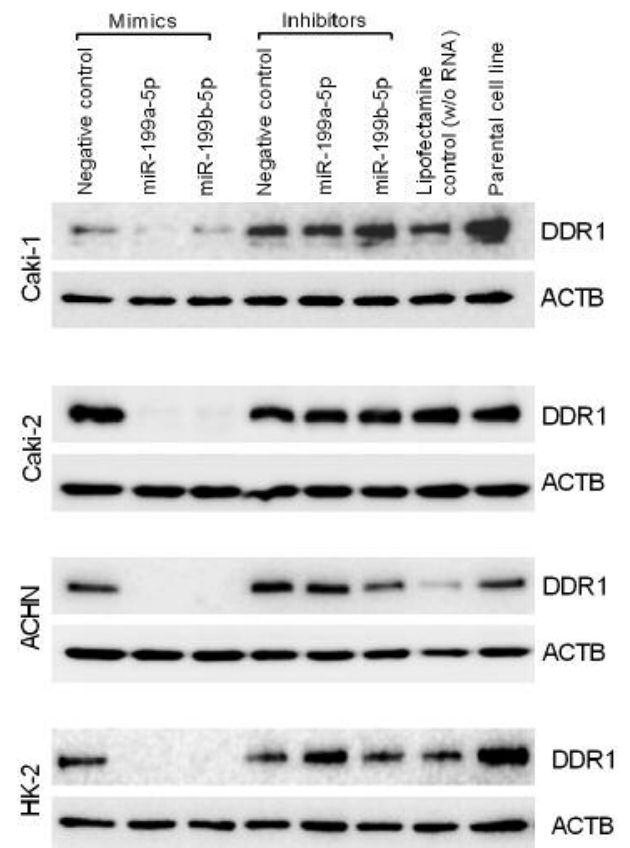

Figure 6. Effect of transfection with miR-199a-5p or miR-199b-5p mimics ( $A$ and B) or inhibitors (C and D) on discoidin domain receptor tyrosine kinase 1 (DDR1) expression in Caki-1, Caki-2, ACHN and HK-2 cells. DDR1 mRNA and protein levels were assessed by quantitative polymerase chain reaction and western blotting, respectively. (E) Representative western blots show DDR1 expression in cells transfected with miR-199a-5p or miR-199b-5p mimics, inhibitors and control RNA sequences as well as cells incubated in control conditions, in media with addition of Lipofectamine RNAiMAX only or without any additives (parental cell line). ${ }^{* *} p<0.01 ; * * *<0.001$. ACTB: Actin beta. 
ccRCC. Furthermore, these findings were validated in vitro by the transfection of three renal cancer cell lines and one PCTderived epithelial cell line with respective mimic RNA sequences that resulted in significant $D D R l$ silencing.

In the present study, RT-qPCR, WB and IHC were used to investigate the expression of $D D R 1$ gene in the tumor and normal renal tissue specimens collected from patients with ccRCC treated by nephrectomy. Tissue homogenates of ccRCC tumors exhibited consistent decrease in DDRl expression at the mRNA and protein levels. Interestingly, IHC analysis revealed a differential pattern of DDR1 expression in cancer cells, disclosing the two distinct localizations of this protein within the membrane/cytoplasmatic and nuclear compartments These findings are in accordance with the data available at The Human Protein Atlas website that indicate two major subcellular localizations for DDR1 protein expression in the nucleoplasm and cell membrane as it was shown in human MCF7 cells by immunofluorescence (27). The results of our study indicate that the levels of DDR1 protein could have a prognostic significance in ccRCC. Lower levels of DDR1 protein were associated with higher Fuhrman grade and worse patients' outcome, although it did not achieve the status of independent prognostic factor in the analyzed cohort of patients. Our results are supported by the analysis of survival data of 528 patients with ccRCC provided by The Cancer Genome Atlas (TCGA) (28), which showed that low expression levels of $D D R I$ measured by RNA-seq is an unfavorable prognostic factor in this type of renal cancer $(p<0.0001)(17)$. However, the latter and our observations are not in line with the results of an immunohistochemical study by Song et al. (16) who found that the immunoreactivity of DDR1 positively correlated with the progression of ccRCC and shorter OS of 119 patients with ccRCC. Although the same antibody directed against human DDR1 was used as in the study by Song and co-workers (16), similar correlations were not observed for membrane/cytoplasmic or nuclear DDR1 immunoreactivity. However, it has to be noted that Song et al. (16) neither distinguished the DDR1 immunoexpression in the cellular compartments nor quantified it, and, moreover, did not show representative microphotographs.

Conflicting results suggesting that DDR1 could either promote or suppress tumor progression, have been disclosed using other types of human cancers (15). An oncogenic role of DDR1 was proposed on the basis of a number of studies that investigated patients' samples and/or cancer cell lines derived from the tumors that arose in the lung $(29,30)$, breast $(31,32)$, ovary (33), pancreas (34), liver (35), prostate (36), large intestine (37), stomach (38), liver (35), pancreas (34), and skin (39). Analogous observations were made in the case of glioma (40) and acute myeloid leukemia $(41,42)$. In most of these studies $D D R 1$ overexpressed and its levels correlated with the progression of disease and worse patients' outcome. Nevertheless, several studies demonstrated that DDR1 can have also a putative tumor suppressing role. Low levels of DDR1 immunoreactivity were associated with worse patients' outcome in non-small cell lung cancer (43) and triple-negative breast cancer (44). Furthermore, it has been shown that loss of DDR1 protein is associated with aggressive and metastatic potential of breast cancer cells (45). Various mechanisms of tumor suppressing activity of DDR1 were proposed, including the involvement of DDR1 in the up-regulation of antiapoptotic factors such as Bcl-2-interacting killer (46) and block of EMT by promotion of E-cadherin stability and E-cadherin-mediated adhesion (47) or decrease of actomyosin contractility at cellto-cell junctions (48). Interestingly, while the epithelial ovarian cancer generally exhibited DDR1 overexpression, its silencing by $\mathrm{CpG}$ methylation was concomitant with the progression of EMT as observed in the tumor samples and cell lines (49). Altogether, the results of our and other studies emphasize the controversial nature of DDR1 in human malignancies and denote that its exact role may depend on many factors including stage of the disease and overall pathological or physiological context. Thus, the role of DDR1 in a given cancer type is of particular interest because this receptor is considered as a putative target of novel adjuvant therapies that are in preclinical development (14), however, lack of consensus regarding the role of DDR1 in many cancers does not support anticancer use of DDR1 inhibitors. Indeed, the analysis of DDR1 phosphorylation in two types of RCC showed that it may be phosphorylated in papillary, rather than in clear cell renal tumors (50). Therefore, DDR1 inhibitors could be less, if any, beneficial in the treatment of ccRCC than it was expected on the basis of recent in vitro studies (16).

In the present study, the expression of miR-199a-5p and miR-199b-5p was found, in line with the previous studies, to be reduced in ccRCC $(51,52)$. Despite the overall downregulation of miR-199a-5p in ccRCC, in our study, its higher (as compared to median value) expression levels correlated with bigger tumor size and tended to correlate with higher Fuhrman grade. Nonetheless, none of the analyzed miRs revealed to have a prognostic significance in our cohort of patients. In contrast, in the studies of Si et al. (51) and Tsukigi et al. (52) down-regulation of miR-199a-5p was associated with higher $\mathrm{T}$ status and unfavorable prognosis. However, these discrepancies may be the result of heterogeneity of RCC subtypes included in the cited studies and/or usage of RNU6 for the quantification of miR expression $(51,52)$, since this small nuclear RNA is not recommended as miRs' normalizer in RCCs (53).

Previous studies documented that DDRl expression can be regulated at the transcription level by factors such as tumor protein p53 (TP53) and zinc finger E-box binding homeobox 1 (13) or promoter CpG methylation (49). DDRl expression may be also controlled post-transcriptionally by the two highly similar miRs, miR-199a-5p and miR-199b-5p as found in hepatocellular carcinoma (35), acute myeloid 
Table IV. Univariate and multivariate Cox regression analysis of the overall survival rates associated with different prognostic variables in patients with clear cell renal cell carcinoma.

\begin{tabular}{|c|c|c|c|c|c|c|}
\hline \multirow[t]{2}{*}{ Parameter } & \multicolumn{3}{|c|}{ Univariate Cox regression } & \multicolumn{3}{|c|}{ Multivariate Cox regression } \\
\hline & HR & $95 \% \mathrm{CI}$ & $p$-Value & HR & $95 \% \mathrm{CI}$ & $p$-Value \\
\hline \multicolumn{7}{|l|}{ DDR1 mRNA level in ccRCC } \\
\hline (low $v s$. high) & 0.85 & $0.37-1.98$ & 0.7130 & & & \\
\hline \multicolumn{7}{|l|}{ DDR1 protein OD level in ccRCC } \\
\hline (low vs. high) & 3.04 & $1.22-7.58$ & 0.0169 & 1.63 & $0.58-4.59$ & 0.3526 \\
\hline $\begin{array}{l}\text { DDR1 membrane/cytoplasmic immunoreactivity in ccRCC cells } \\
\text { (negative } v s \text {. positive) }\end{array}$ & 1.07 & $0.46-2.46$ & 0.8818 & & & \\
\hline \multicolumn{7}{|l|}{ DDR1 nuclear } \\
\hline \multicolumn{7}{|l|}{ immunoreactivity in ccRCC cells } \\
\hline \multicolumn{7}{|l|}{ miR-199a-5p level in ccRCC } \\
\hline \multicolumn{7}{|l|}{ miR-199b-5p level in ccRCC } \\
\hline (low vs. high) & 0.80 & $0.35-1.86$ & 0.6102 & & & \\
\hline Gender (women $v s$. men) & 0.56 & $0.23-1.33$ & 0.1889 & & & \\
\hline Age ( $\geq 62$ vs. $<62$ years old) & 0.84 & $0.36-1.93$ & 0.6736 & & & \\
\hline Tumor size $(\geq 6 v s .<6 \mathrm{~cm})$ & 3.61 & $1.33-9.81$ & 0.0117 & 1.17 & $0.27-5.00$ & 0.8303 \\
\hline $\mathrm{T}$ status $(\mathrm{T} 3 v s . \mathrm{T} 1+\mathrm{T} 2)$ & 4.00 & $1.55-10.3$ & 0.0041 & 1.75 & $0.45-6.86$ & 0.4198 \\
\hline Fuhrman grade (G3 vs. G1 + G2) & 6.44 & $2.53-16.4$ & 0.0001 & 2.36 & $0.66-8.43$ & 0.1854 \\
\hline Distant metastases (present $v s$. absent) & 4.62 & $1.90-11.3$ & 0.0008 & 1.94 & $0.63-5.95$ & 0.2488 \\
\hline
\end{tabular}

Median follow-up time, 40.6 months. Significant $p$-values $(<0.05)$ are shown in bold. HR: Hazard ratio; CI: confidence interval.

Table V. Correlations between the expression of discoidin domain receptor tyrosine kinase 1 (DDR1) and miR-199a-5p/miR-199b-5p levels in the clear cell renal cell carcinoma specimens.

\begin{tabular}{lcccc}
\hline Spearman's correlation of: & \multicolumn{2}{c}{$v s$. miR-199a-5p } & & \multicolumn{2}{c}{$v s$. miR-199b-5p } \\
\cline { 2 - 3 } & Rho & $p$-Value & & Rho \\
\hline DDR1 mRNA level & 0.1806 & 0.1829 & 0.1814 & 0.1809 \\
DDR1 protein OD level & 0.2474 & 0.0660 & 0.3438 & $\mathbf{0 . 0 0 9 5}$ \\
DDR1 membrane/cytoplasmic immunoreactivity & 0.0134 & 0.9220 & 0.1352 & 0.3205 \\
DDR1 nuclear immunoreactivity & 0.3136 & $\mathbf{0 . 0 1 8 6}$ & & 0.3179 \\
\hline
\end{tabular}

Significant $p$-values $(<0.05)$ are shown in bold.

leukemia (42), colorectal cancer (37), cutaneous squamous cell carcinoma (39) or triple-negative breast cancer (54). The expression levels of miR-199a-5p or miR-199b-5p were negatively correlated with DDR 1 protein content in the ccRCC tissues, suggesting that those two miRs may repress DDRl in ccRCC. To validate this hypothesis, RCC cell lines Caki-1, Caki-2, ACHN and PCT epithelium HK-2 cells were transfected with RNA sequences that mimicked or inhibited miR-199a-5p or miR-199b-5p. Transfection with 199a-5p and miR-199b-5p mimics resulted in a noticeable reduction in $D D R l$ expression at the transcript and protein levels. However, no significant effect of miRs inhibitors was observed. The latter could be attributed to the low levels of endogenous miR-199a-5p and miR-199b-5p expression in the renal cancer cell lines as it was reported previously by Tsukigi et al. (52).

The results of the present study disclose that DDR1 immunoreactivity can be found in two distinct subcellular localizations within the ccRCC cells. Nuclear immunoexpression of DDR1 was up-regulated in cancer cells and was positively correlated with the contents of miR199a-5p and miR-199b-5p. These observations suggest that those miRs, besides their ability to repress overall $D D R 1$ expression, could also have an impact on the trafficking of DDR 1 protein and may promote DDR1 nuclear localization in ccRCC cells. However, the exact, direct or indirect, 
mechanisms underlaying this phenomenon remain unknown. To date, five DDR1 isoforms resulting from alternative splicing, deletions and frame-shift mutations have been described (55) and it has been proposed that the role of DDR1 in human cancer can be isoform-specific (13). Herein, we showed that miR-199a-5p and miR-199b-5p target $D D R I$ expression in renal cancer cells and the isoform-dependent character of this process cannot be excluded. A study carried out on mouse embryonic stem cells demonstrated that alternative transcript variants of oncologically relevant genes can be targeted by distinct miRs (56). In another study the tumor-associated miRs were shown to act by targeting the splicing machinery and as a result they potentiated the expression of cancer-specific isoforms of pyruvate kinase M1/2 glycolytic enzyme during the tumor development (57). Further studies are necessary to identify the mechanisms and relationships within the miR-199a/b-5p/DDR1 network and evaluate their prognostic and predictive relevance in ccRCC.

In summary, the first comprehensive investigation analyzing the expression of receptor tyrosine kinase $D D R l$ in a cohort of patients with ccRCC is presented. Evidence is provided indicating that $D D R l$ expression is altered in ccRCC and DDR1 protein levels correlate with clinicopathological parameters and OS of the patients. However, DDR1 could not serve as an independent prognostic factor in ccRCC. Our findings do not support an oncogenic role of DDR1 in this cancer type. In addition, we demonstrated that the expression levels of miR-199a-5p and miR-199b-5p are down-regulated in ccRCC. Since the altered DDR1 expression is correlated with the levels of miR-199a-5p and miR-199b-5p, the exact role of these miRs in ccRCC should be in-depth investigated.

\section{Conflicts of Interest}

The Authors declare that they have no competing interests regarding this study.

\section{Authors' Contributions}

BEK, JK and ZK initiated and designed the study. JGo and PK collected clinical samples; JGo collected clinicopathological and survival data. JGr and PD performed immunohistochemistry and evaluated immunoreactivity scores. BEK, JK, ASJ and AEK performed cell cultures, qPCR and western blot assays. BEK performed the statistical analysis. The manuscript was drafted by BEK and JK and proof-read by ZK. JK and BEK were managing the project.

\section{Acknowledgements}

This study was supported by the National Science Centre (Poland) grant no. 2012/05/B/NZ4/01832. The Authors wish to thank Dr. Aleksandra Piotrowska from the Department of Human Morphology and Embryology, Division of Histology and Embryology, Wroclaw Medical University for technical support.

\section{References}

1 Capitanio U, Bensalah K, Bex A, Boorjian SA, Bray F, Coleman J, Gore JL, Sun M, Wood C and Russo P: Epidemiology of renal cell carcinoma. Eur Urol 75(1): 74-84, 2019. PMID: 30243799. DOI: $10.1016 /$ j.eururo.2018.08.036

2 Greef B and Eisen T: Medical treatment of renal cancer: New horizons. Br J Cancer 115(5): 505-516, 2016. PMID: 27490806. DOI: $10.1038 /$ bjc. 2016.230

3 Haake SM and Rathmell WK: Renal cancer subtypes: Should we be lumping or splitting for therapeutic decision making? Cancer 123(2): 200-209, 2017. PMID: 27861752. DOI: 10.1002/cncr.30314

4 Bhatt JR and Finelli A: Landmarks in the diagnosis and treatment of renal cell carcinoma. Nat Rev Urol 11(9): 517-525, 2014. PMID: 25112856. DOI: 10.1038/nrurol.2014.194

5 Keefe SM, Nathanson KL and Kimryn Rathmell W: The molecular biology of renal cell carcinoma. Semin Oncol 40(4): 421-428, 2013. PMID: 23972705. DOI: 10.1053/j.seminoncol.2013.05.006

6 Shoji S, Nakano M, Sato H, Tang XY, Osamura YR, Terachi T, Uchida $\mathrm{T}$ and Takeya K: The current status of tailor-made medicine with molecular biomarkers for patients with clear cell renal cell carcinoma. Clin Exp Metastasis 31(1): 111-134, 2014. PMID: 23959576. DOI: 10.1007/s10585-013-9612-7

7 Johnson JD, Edman JC and Rutter WJ: A receptor tyrosine kinase found in breast carcinoma cells has an extracellular discoidin I-like domain. Proc Natl Acad Sci USA 90(12): 56775681, 1993. PMID: 8390675. DOI: 10.1073/pnas.90.12.5677

8 Shrivastava A, Radziejewski C, Campbell E, Kovac L, McGlynn M, Ryan TE, Davis S, Goldfarb MP, Glass DJ, Lemke G and Yancopoulos GD: An orphan receptor tyrosine kinase family whose members serve as nonintegrin collagen receptors. Mol Cell 1(1): 25-34, 1997. PMID: 9659900. DOI: 10.1016/S10972765(00)80004-0

9 Vogel WW: Discoidin domain receptors: Structural relations and functional implications. Faseb J 13(Suppl): S77-82, 1999. PMID: 10352148. DOI: 10.1096/fasebj.13.9001.s77

10 Vogel W, Gish GD, Alves F and Pawson T: The discoidin domain receptor tyrosine kinases are activated by collagen. Mol Cell 1(1): 13-23, 1997. PMID: 9659899. DOI: 10.1016/S10972765(00)80003-9

11 Leitinger B: Discoidin domain receptor functions in physiological and pathological conditions. Int Rev Cell Mol Biol 310: 39-87, 2014. PMID: 24725424. DOI: 10.1016/B978-0-12800180-6.00002-5

12 Borza CM and Pozzi A: Discoidin domain receptors in disease. Matrix Biol 34: 185-192, 2014. PMID: 24361528. DOI: 10.1016/j.matbio.2013.12.002

13 Valiathan RR, Marco M, Leitinger B, Kleer CG and Fridman R: Discoidin domain receptor tyrosine kinases: New players in cancer progression. Cancer Metastasis Rev 31(1-2): 295-321, 2012. PMID: 22366781. DOI: 10.1007/s10555-012-9346-Z

14 Ambrogio C, Darbo E, Lee SW and Santamaría D: A putative role for discoidin domain receptor 1 in cancer chemoresistance. Cell Adh Migr 12(4): 394-397, 2018. PMID: 29505315. DOI: $10.1080 / 19336918.2018 .1445954$

15 Henriet E, Sala M, Abou Hammoud A, Tuariihionoa A, Di Martino J, Ros M and Saltel F: Multitasking discoidin domain receptors are involved in several and specific hallmarks of cancer. Cell Adh Migr 12(4): 363-377, 2018. PMID: 29701112. DOI: $10.1080 / 19336918.2018 .1465156$ 
16 Song J, Chen X, Bai J, Liu Q, Li H, Xie J, Jing H and Zheng J: Discoidin domain receptor 1 (DDR1), a promising biomarker, induces epithelial to mesenchymal transition in renal cancer cells. Tumor Biol 37(8): 11509-11521, 2016. PMID: 27020590. DOI: $10.1007 / \mathrm{s} 13277-016-5021-2$

17 Uhlen M, Zhang C, Lee S, Sjöstedt E, Fagerberg L, Bidkhori G, Benfeitas R, Arif M, Liu Z, Edfors F, Sanli K, von Feilitzen K, Oksvold P, Lundberg E, Hober S, Nilsson P, Mattsson J, Schwenk JM, Brunnström H, Glimelius B, Sjöblom T, Edqvist PH, Djureinovic D, Micke P, Lindskog C, Mardinoglu A and Ponten F: A pathology atlas of the human cancer transcriptome. Science 357(6352): eaan2507, 2017. PMID: 28818916. DOI: 10.1126/science.aan2507

18 Greene FL, Page DL, Fleming ID, Fritz AG, Balch CM, Haller DG and Morrow M: Kidney. In: American Joint Committee on Cancer: AJCC Cancer Staging Manual. 6th edition. Springer, New York, NY, pp. 323-328, 2002.

19 Godlewski J, Krazinski BE, Kowalczyk AE, Kiewisz J, Kiezun J, Kwiatkowski P, Sliwinska-Jewsiewicka A, Maslowski Z and Kmiec Z: PLAGL1 (ZAC1/LOT1) expression in clear cell renal cell carcinoma: Correlations with disease progression and unfavorable prognosis. Anticancer Res 36(2): 617-624, 2016. PMID: 26851016.

20 Fuhrman SA, Lasky LC and Limas C: Prognostic significance of morphologic parameters in renal cell carcinoma. Am J Surg Pathol 6(7): 655-663, 1982. PMID: 7180965.

21 Kowalczyk AE, Krazinski BE, Godlewski J, Kiewisz J, Kwiatkowski P, Sliwinska-Jewsiewicka A, Kiezun J, Wierzbicki PM, Bodek G, Sulik M and Kmiec Z: Altered expression of the PLAGL1 (ZAC1/LOT1) gene in colorectal cancer: Correlations to the clinicopathological parameters. Int J Oncol 47(3): 951962, 2015. PMID: 26134521. DOI: 10.3892/ijo.2015.3067

22 Godlewski J, Krazinski BE, Kowalczyk AE, Kiewisz J, Kiezun J, Kwiatkowski P, Sliwińska-Jewsiewicka A, Wierzbicki PW and Kmieć Z: Expression and prognostic significance of EP300, TP53 and BAX in clear cell renal cell carcinoma. Anticancer Res 37(6): 2927-2937, 2017. PMID: 28551630. DOI: 10.21873/ anticanres.11646.

23 Livak KJ and Schmittgen TD: Analysis of relative gene expression data using real-time quantitative PCR and the 2$\triangle \triangle \mathrm{CT}$ method. Methods 25(4): 402-408, 2001. PMID: 11846609. DOI: $10.1006 /$ meth.2001.1262

24 Kowalczyk AE, Krazinski BE, Godlewski J, Grzegrzolka J, Kiewisz J, Kwiatkowski P, Sliwinska-Jewsiewicka A, Dziegiel $\mathrm{P}$ and Kmiec Z: SATB1 is down-regulated in clear cell renal cell carcinoma and correlates with MIR-21-5p overexpression and poor prognosis. Cancer Genomics Proteomics 13(3): 209-218, 2016. PMID: 27107063.

25 Kowalczyk AE, Godlewski J, Krazinski BE, Kiewisz J, SliwinskaJewsiewicka A, Kwiatkowski P, Pula B, Dziegiel P, Janiszewski J, Wierzbicki PM and Kmiec Z: Divergent expression patterns of SATB1 mRNA and SATB1 protein in colorectal cancer and normal tissues. Tumor Biol 36(6): 4441-4452, 2015. PMID: 25874491. DOI: $10.1007 / \mathrm{s} 13277-015-3084-0$

26 Remmele W and Stegner HE: Recommendation for uniform definition of an immunoreactive score (IRS) for immunohistochemical estrogen receptor detection (ER-ICA) in breast cancer tissue. Pathologe 8(3): 138-140, 1987. PMID: 3303008.

27 Thul PJ, Åkesson L, Wiking M, Mahdessian D, Geladaki A, Ait Blal H, Alm T, Asplund A, Björk L, Breckels LM, Bäckström A,
Danielsson F, Fagerberg L, Fall J, Gatto L, Gnann C, Hober S, Hjelmare M, Johansson F, Lee S, Lindskog C, Mulder J, Mulvey CM, Nilsson P, Oksvold P, Rockberg J, Schutten R, Schwenk JM, Sivertsson Å, Sjöstedt E, Skogs M, Stadler C, Sullivan DP, Tegel H, Winsnes C, Zhang C, Zwahlen M, Mardinoglu A, Pontén F, von Feilitzen K, Lilley KS, Uhlén M and Lundberg E: A subcellular map of the human proteome. Science 356(6340): eaal3321, 2017. PMID: 28495876. DOI: 10.1126/science.aal3321

28 Cancer Genome Atlas Research Network: Comprehensive molecular characterization of clear cell renal cell carcinoma. Nature 499(7456): 43-49, 2013. PMID: 23792563. DOI: 10.1038 /nature 12222

29 Valencia K, Ormazábal C, Zandueta C, Luis-Ravelo D, Antón I, Pajares MJ, Agorreta J, Montuenga LM, Martínez-Canarias S, Leitinger B and Lecanda F: Inhibition of collagen receptor discoidin domain receptor-1 (DDR1) reduces cell survival, homing, and colonization in lung cancer bone metastasis. Clin Cancer Res 18(4): 969-980, 2012. PMID: 22223527. DOI: 10.1158/1078-0432.CCR-11-1686

30 Yang SH, Baek HA, Lee HJ, Park HS, Jang KY, Kang MJ, Lee DG, Lee YC, Moon WS and Chung MJ: Discoidin domain receptor 1 is associated with poor prognosis of non-small cell lung carcinomas. Oncol Rep 24(2): 311-319, 2010. PMID: 20596615. DOI: 10.3892/or_00000861

31 Alves F, Vogel WF and Aszo A: Discoidin domain receptor 1 tyrosine kinase has an essential role in mammary gland development. Mol Cell Biol 21(8): 2906-2917, 2001. PMID: 11283268. DOI: 10.1128/MCB.21.8.2906

32 Belfiore A, Malaguarnera R, Nicolosi ML, Lappano R, Ragusa $\mathrm{M}$, Morrione A and Vella V: A novel functional crosstalk between DDR 1 and the IGF axis and its relevance for breast cancer. Cell Adh Migr 12(4): 305-314, 2018. PMID: 29486622. DOI: 10.1080/19336918.2018.1445953

33 Quan J, Yahata T, Adachi S, Yoshihara K and Tanaka K: Identification of receptor tyrosine kinase, discoidin domain receptor 1 (DDR1), as a potential biomarker for serous ovarian cancer. Int J Mol Sci 12(2): 971-982, 2011. PMID: 21541037. DOI: $10.3390 /$ ijms 12020971

34 Huo Y, Yang M, Liu W, Yang J, Fu X, Liu D, Li J, Zhang J, Hua $\mathrm{R}$ and Sun Y: High expression of DDR1 is associated with the poor prognosis in Chinese patients with pancreatic ductal adenocarcinoma. J Exp Clin Cancer Res 34(1): 88, 2015. PMID: 26297342. DOI: 10.1186/s13046-015-0202-1

35 Shen Q, Cicinnati VR, Zhang X, Iacob S, Weber F, Sotiropoulos GC, Radtke A, Lu M, Paul A, Gerken G and Beckebaum S: Role of microRNA-199a-5p and discoidin domain receptor 1 in human hepatocellular carcinoma invasion. Mol Cancer 9: 227, 2010. PMID: 20799954. DOI: 10.1186/1476-4598-9-227

36 Shimada K, Nakamura M, Ishida E, Higuchi T, Yamamoto H, Tsujikawa K and Konishi N: Prostate cancer antigen-1 contributes to cell survival and invasion though discoidin receptor 1 in human prostate cancer. Cancer Sci 99(1): 39-45, 2008. PMID: 17970783. DOI: 10.1111/j.1349-7006.2007.00655.x

$37 \mathrm{Hu}$ Y, Liu J, Jiang B, Chen J, Fu Z, Bai F, Jiang J and Tang Z: MiR-199a-5p loss up-regulated DDR1 aggravated colorectal cancer by activating epithelial-to-mesenchymal transition related signaling. Dig Dis Sci 59(9): 2163-2172, 2014. PMID: 24711074. DOI: $10.1007 / \mathrm{s} 10620-014-3136-0$

38 Hur H, Ham I-H, Lee D, Jin H, Aguilera KY, Oh HJ, Han S-U, Kwon JE, Kim Y-B, Ding K and Brekken RA: Discoidin domain 
receptor 1 activity drives an aggressive phenotype in gastric carcinoma. BMC Cancer 17(1): 87, 2017. PMID: 28143619. DOI: $10.1186 / \mathrm{s} 12885-017-3051-9$

39 Kim BK, Kim I and Yoon SK: Identification of miR-199a-5p target genes in the skin keratinocyte and their expression in cutaneous squamous cell carcinoma. J Dermatol Sci 79(2): 137-147, 2015. PMID: 26026896. DOI: 10.1016/j.jdermsci.2015.05.005.

40 Ram R, Lorente G, Nikolich K, Urfer R, Foehr E and Nagavarapu U: Discoidin domain receptor-1a (DDR1a) promotes glioma cell invasion and adhesion in association with matrix metalloproteinase-2. J Neurooncol 76(3): 239-248, 2006. PMID: 16234985. DOI: 10.1007/s11060-005-6874-1

41 Chiaretti S, Li X, Gentleman R, Vitale A, Wang KS, Mandelli F, Foà R and Ritz J: Gene expression profiles of B-lineage adult acute lymphocytic leukemia reveal genetic patterns that identify lineage derivation and distinct mechanisms of transformation. Clin Cancer Res 11(20): 7209-7219, 2005. PMID: 16243790. DOI: $10.1158 / 1078-0432 . C C R-04-2165$

42 Favreau AJ, Cross EL and Sathyanarayana P: miR-199b-5p directly targets PODXL and DDR1 and decreased levels of miR199b-5p correlate with elevated expressions of PODXL and DDR1 in acute myeloid leukemia. Am J Hematol 87(4): 442446, 2012. PMID: 22374871. DOI: 10.1002/ajh.23129

43 Ford CE, Lau SK, Zhu CQ, Andersson T, Tsao MS and Vogel WF: Expression and mutation analysis of the discoidin domain receptors 1 and 2 in non-small cell lung carcinoma. Br J Cancer 96(5): 808814, 2007. PMID: 17299390. DOI: 10.1038/sj.bjc.6603614

44 Toy KA, Valiathan RR, Núñez F, Kidwell KM, Gonzalez ME, Fridman R and Kleer CG: Tyrosine kinase discoidin domain receptors DDR1 and DDR2 are coordinately deregulated in triple-negative breast cancer. Breast Cancer Res Treat 150(1): 918, 2015. PMID: 25667101. DOI: 10.1007/s10549-015-3285-7

45 Takai K, Drain AP, Lawson DA, Littlepage LE, Karpuj M, Kessenbrock K, Le A, Inoue K, Weaver VM and Werb Z: Discoidin domain receptor 1 (DDR1) ablation promotes tissue fibrosis and hypoxia to induce aggressive basal-like breast cancers. Genes Dev 32(3-4): 244-257, 2018. PMID: 29483153. DOI: $10.1101 / \mathrm{gad} .301366 .117$

46 Assent D, Bourgot I, Hennuy B, Geurts P, Noël A, Foidart J-M and Maquoi E: A membrane-type-1 matrix metalloproteinase (MT1-MMP)-discoidin domain receptor 1 axis regulates collagen-induced apoptosis in breast cancer cells. PLoS One 10(3): e0116006, 2015. PMID: 25774665. DOI: 10.1371 /journal.pone.0116006

47 Yeh Y-C, Wu C-C, Wang Y-K and Tang M-J: DDR1 triggers epithelial cell differentiation by promoting cell adhesion through stabilization of E-cadherin. Mol Biol Cell 22(7): 940-53, 2011. PMID: 21289093. DOI: 10.1091/mbc.E10-08-0678.

48 Hidalgo-Carcedo C, Hooper S, Chaudhry SI, Williamson P, Harrington K, Leitinger B and Sahai E: Collective cell migration requires suppression of actomyosin at cell-cell contacts mediated by DDR 1 and the cell polarity regulators Par3 and Par6. Nat Cell Biol 13(1): 49-58, 2011. PMID: 21170030. DOI: 10.1038/ ncb2133
49 Chung VY, Tan TZ, Huang RL, Lai HC and Huang RYJ: Loss of discoidin domain receptor 1 (DDR1) via $\mathrm{CpG}$ methylation during EMT in epithelial ovarian cancer. Gene 635(3-4): 9-15, 2017. PMID: 28887161. DOI: 10.1016/j.gene.2017.09.001

50 Haake SM, Li J, Bai Y, Kinose F, Fang B, Welsh EA, Zent R, Dhillon J, Pow-Sang JM, Chen YA, Koomen JM, Rathmell WK, Fishman $\mathrm{M}$ and Haura EB: Tyrosine kinase signaling in clear cell and papillary renal cell carcinoma revealed by mass spectrometry-based phosphotyrosine proteomics. Clin Cancer Res 22(22): 5605-5616, 2016. PMID: 27220961. DOI: 10.1158/ 1078-0432.CCR-15-1673

51 Si T, Liu C, Xu K and Gui Y: Association of miR-199a expression with clinicopathologic characteristics and prognosis of renal cell carcinoma. Nan Fang Yi Ke Da Xue Xue Bao 32(11): 1568-1571, 2012. PMID: 23174576. DOI: 10.3969/ j.issn.1673-4254.2012.11.008

52 Tsukigi M, Bilim V, Yuuki K, Ugolkov A, Naito S, Nagaoka A, Kato T, Motoyama T and Tomita Y: Re-expression of miR-199a suppresses renal cancer cell proliferation and survival by targeting GSK-3 $\beta$. Cancer Lett 315(2): 189-197, 2012. PMID: 22093618. DOI: $10.1016 /$ j.canlet.2011.10.008

53 Wotschofsky Z, Meyer HA, Jung M, Fendler A, Wagner I, Stephan C, Busch J, Erbersdobler A, Disch AC, Mollenkopf HJ and Jung K: Reference genes for the relative quantification of microRNAs in renal cell carcinomas and their metastases. Anal Biochem 417(2): 233-241, 2011. PMID: 21741950. DOI: 10.1016/j.ab.2011.06.009

54 Wu A, Chen Y, Liu Y, Lai Y and Liu D: miR-199b-5p inhibits triple negative breast cancer cell proliferation, migration and invasion by targeting DDR1. Oncol Lett 16(4): 4889-4896, 2018. PMID: 30250555. DOI: 10.3892/ol.2018.9255

55 Alves F, Saupe S and Ledwon M: Identification of two novel, kinase-deficient variants of discoidin domain receptor 1: differential expression in human colon cancer cell lines. FASEB J 2(1): 1321-1323, 2001. PMID: 11344127. DOI: 10.1096/fj.00

56 Salomonis N, Schlieve CR, Pereira L, Wahlquist C, Colas A, Zambon AC, Vranizan K, Spindler MJ, Pico AR, Cline MS, Clark TA, Williams A, Blume JE, Samal E, Mercola M, Merrill BJ and Conklin BR: Alternative splicing regulates mouse embryonic stem cell pluripotency and differentiation. Proc Natl Acad Sci USA 107(23): 10514-10519, 2010. PMID: 20498046. DOI: 10.1073 /pnas.0912260107

57 Taniguchi K, Ito Y, Sugito N, Kumazaki M, Shinohara H, Yamada N, Nakagawa Y, Sugiyama T, Futamura M, Otsuki Y, Yoshida K, Uchiyama K and Akao Y: Organ-specific PTB1associated microRNAs determine expression of pyruvate kinase isoforms. Sci Rep 5: 8647, 2015. PMID: 25721733. DOI: $10.1038 /$ srep08647
Received February 27, 2019

Revised March 19, 2019

Accepted March 20, 2019 